\title{
An Assessment of Prison Overcrowding in Nigeria: Implications for Rehabilitation, Reformation and Reintegration of Inmates.
}

\author{
Awopetu Ronke Grace $(\mathrm{PhD})$ \\ Department of Psychology, Benue State University, Makurdi
}

\begin{abstract}
In recent times, prisons in Nigeria have witnessed unprecedented increase in the admission of prison inmates. This alarming rate turns out to housing prison inmates beyond the capacity at which most prisons were built for. It then hinders the goals of reformations, rehabilitation and reintegration. As a result, this study assesses the capacity and current lockup of prison population in six geo-political zones of the Nigeria. Based on this assessment, it was discovered that most prisons across the zones were housing more than capacity in which they were originally built for, while majority of the inmates are awaiting trials. This clustering and crowding of prisoners together in a choky cell that in originally may be meant for five inmates and housing 20 - 30 inmates may arouse prison violence, aggressive behaviour and reduce the quality and sense of psychological wellbeing of the inmates. It is therefore recommended that programs and policies that will increase the wellbeing of the prison inmates should be embraced as this will improve the lives of the inmates and the aim of reformation, rehabilitation and reintegration of prison inmates back to the larger society can be achieved.
\end{abstract}

Keywords: Prison Overcrowding, Rehabilitation, Reformation, Reintegration, Inmates

\section{Introduction}

Overcrowding in Nigeria prisons occurs where the numbers of prisoners exceeds prison capacity to an extent inmates cannot be housed in a humane, healthy and psychological manner. In Nigeria, overcrowding is generally called congestion. It constitutes a serious challenge in Nigeria prisons especially in prisons located in the metropolitan cities. In such prisons, cells in Nigeria, facilities hold as many as twice or thrice their capacity. In such cells there is hardly enough room for prison inmates to move body and limbs freely. In such state each prisoner is allocated a "post" which approximately is a space of a foot and a half.

Majority of the prisons in Nigeria are congested and overcrowded and this create enormous problem in prison management process in terms of reformation, rehabilitation and reintegration. The capacity of Nigerian prisons has remained virtually the same for the past two decades not withstanding the alarming increase in prison population. These prisons were built by the colonial administration and native authority predating to the era Nigeria gain independence in 1960. The conditions of these prisons are in an alarming state of despair with no sense of maintenance or renovation reflective of long neglect by the Nigeria government. In fact, most of the prisons constructed at this period are old, in bad shape and at the brinks of collapse. However, few prisons have been constructed with most substandard materials, which are a far cry from modern prisons across the globe. Examples of such new prisons include, Gusua Medium Prison, Kebbi new Prisons (1991), Medium Security Prisons Kirikiri (1993), Funtia (2003), Oyo and Eket Prisons (2007) respectively.

Considering the act of imprisonment as the most effective form of sanctions of offenders, nevertheless, in the last few decades, inmate's population in Nigeria have grown substantially, to the extent leading to overcrowding. The overcrowding tends to alter the psychological, physiological and behavioural wellbeing of the inmates (Crystal, 2004). The massive influx of inmates that begun in recent times as a result of delay in judiciary process has produced a rate of growth in the nation's inmates population that scholars and legal commentators have repeatedly described and characterized as unprecedented. Aduba (2005) reported that the total prison capacity during the period of 1978 to 1981 was 27,257 , but it was revealed that in 1978 , the average monthly population was 32,332; in 1979 it was 34,770; in 1980, it was 35,332; and in 1981 it was 38,477 (Nigeria prison services, 1978-1981). The percentage of 'overcrowding' thus was 18.61 in 1978, 27.56 in 1979, 29.43 in 1980, and 41.16 in 1981. Currently, Nigeria prisons are housing 49,000 in two hundred and thirty four prisons out of which $20 \%$ are convicts while the rest are awaiting trial inmates (Amnesty International Report, 2012).This imaginable condition of overcrowding is relatively easy to recognise when one sees it situations where there is no enough room for prisoners to sleep; no facilities to provide enough food, health care or any form of constructive activities; insufficient staff to ensure that prisoners are safe; lack of accommodation to hold separately types of prisoners who should be kept apart- juveniles from adult; awaiting trails from convicted, or lack of capacity to admit any more numbers so that emergency measures have to be taken in the form of amnesty, emergency accommodation or the holding of prisoners in police custody. 


\section{An overview of prison population in Nigeria}

Overcrowding in Nigeria according to Nigerian Prisons Service Statistic as at $30^{\text {th }}$ June, 2011, (Dept. Of statistics PHQ, Abuja) and prisons audit is a phenomenon in prisons in urban centres. Ayade (2010) observed prison congestion in Nigeria, and noted the trend of congestion on selected prisons, the same prisons were audited by the National Human Rights Commission in collaboration with the United Nations Development Project and Norwegian Agency for Development Corporation as presented in the tables below:

Table (1): Capacity, Lockup Number of Awaiting Trial Persons and Convicts in North East Zone

\begin{tabular}{|c|c|c|c|c|}
\hline Prison & Capacity & Lock up & Convict & Awaiting trail \\
\hline \multicolumn{5}{|l|}{ Adamawa state } \\
\hline 1. Ganye & 200 & 180 & 83 & 97 \\
\hline 2. Jada & 100 & 104 & 89 & 15 \\
\hline 3. Jimeta & 300 & 412 & 113 & 299 \\
\hline 4. Numan & 400 & 174 & 139 & 35 \\
\hline 5. Michika & 100 & 87 & 40 & 47 \\
\hline 6. Yola Central & 500 & 324 & 149 & 174 \\
\hline \multicolumn{5}{|l|}{ Bauchi State } \\
\hline 7. Azare & 152 & 84 & 61 & 23 \\
\hline 8. Bauchi & 500 & 741 & 111 & 630 \\
\hline 9. Jama' are & 320 & 68 & 56 & 12 \\
\hline 10. Ningi & 110 & 68 & 56 & 12 \\
\hline 11. Misau & 120 & 44 & 39 & 43 \\
\hline \multicolumn{5}{|l|}{ Borno State } \\
\hline 12. Bama & 320 & 67 & 62 & 5 \\
\hline 13. Kukawa Satellite & 72 & 31 & 2 & 29 \\
\hline 14. Biu & 130 & 102 & 80 & 22 \\
\hline 15. Gamboru-Ngala & 76 & 31 & 18 & 13 \\
\hline 16. Gwoza & 680 & 379 & 222 & 157 \\
\hline 17. Maiduguri Farm & 120 & 114 & 114 & Nil \\
\hline 18. Maiduguri New & 680 & - & - & - \\
\hline 19. Maiduguri Maximum & 1,600 & 732 & 273 & 459 \\
\hline 20. Kakawa & 100 & 45 & 18 & 27 \\
\hline 21. Mongono & 36 & 32 & 16 & 16 \\
\hline 22. Kumshe & 50 & 38 & 24 & 14 \\
\hline 23. Konduga & 30 & 26 & 26 & Nil \\
\hline \multicolumn{5}{|l|}{ Taraba State } \\
\hline 24. Gembu & 200 & 128 & 64 & 64 \\
\hline 25. Jalingo & 250 & 408 & 139 & 269 \\
\hline 26. Serti & 150 & 79 & 63 & 16 \\
\hline 27. Wukari & 320 & 179 & 110 & 69 \\
\hline \multicolumn{5}{|l|}{ Yobe State } \\
\hline 28. Gashua & 104 & 123 & 109 & 14 \\
\hline 29. Nguru & 94 & 45 & 45 & 45 \\
\hline 30. Potiskum & 832 & 285 & 130 & 155 \\
\hline $\begin{array}{r}\text { TOTAL } \\
\end{array}$ & 8646 & 5130 & 2321 & 3691 \\
\hline
\end{tabular}

There seems to be no noticeable congestion in this zone Jalingo but what is glaring is that convicts outnumbered the awaiting trial inmates. It is only in few prisons like Yola Bauchi, Jimeta, Maiduguri mazimum, Jalingo, Guluk and Potiskum that have higher awaiting trial inmates than convicts. This zone was operating below capacity as of $30^{\text {th }}$ June, 2010.

Table (2): Capacity, Lockup Number of Awaiting Trial Persons and Convicts in North-West Zone

\begin{tabular}{|l|l|l|l|l|}
\hline Prison & Capacity & Lock up & Convict & Awaiting trial \\
\hline Jigawa state & & & & 16 \\
\hline 1. Kazaure Farm & 150 & 60 & 44 & Nil \\
\hline 2. Birnin Kudu & 300 & 114 & 114 & 30 \\
\hline 3. Kaduna State & 100 & 57 & 27 & 3 \\
\hline 4. Makarfi & 350 & 155 & 152 & 24 \\
\hline 5. Kujama Prison Farm & 100 & 83 & 57 & Nil \\
\hline 6. Birnin Gwari & 208 & 482 & Nil & 96 \\
\hline Kaduna State & & & 122 & 17 \\
\hline 7. BorstalTraining Institute & 378 & 218 & 17 & 534 \\
\hline 8. Zaria & 20 & 54 & 331 & 30 \\
\hline 9. Kafanchan & 548 & 867 & 123 & 567 \\
\hline 10. Katsina State & 110 & 153 & 166 & 190 \\
\hline 11. Katsina & 238 & 733 & 64 & \\
\hline 12. Funtua & 160 & 254 & & \\
\hline Kebbi State & & & \\
\hline
\end{tabular}


An Assessment of Prison Overcrowding in Nigeria: Implications for Rehabilitation, Reformation and

\begin{tabular}{|l|l|l|l|l|}
\hline 1. Zuru & 320 & 112 & 78 & 34 \\
\hline 2. Old Kebbi & 100 & 128 & 75 & 53 \\
\hline $\begin{array}{l}\text { 3. Medium Security } \\
\text { Kebbi }\end{array}$ & 250 & 226 & 226 & 440 \\
\hline 4. Argungu & 532 & 568 & 128 & 441 \\
\hline 5. Yelwa Yuri & 690 & 1,249 & 309 & 912 \\
\hline Sokoto State & & & \\
\hline 6 Sokoto Central & 160 & 129 & 104 & 25 \\
\hline 7. Gusau & 600 & 698 & 284 & 414 \\
\hline Kano State & & & & \\
\hline 8. Kano Central & 690 & 1218 & 309 & 940 \\
\hline 9. Wudil & 160 & 129 & 105 & 122 \\
\hline 10. Goron Dtuse & 600 & 698 & 284 & 414 \\
\hline Total & $\mathbf{6 , 9 6 4}$ & $\mathbf{8 , 3 6 0}$ & $\mathbf{2 , 8 4 4}$ & $\mathbf{5 , 3 2 1}$ \\
\hline
\end{tabular}

In the North West Zone, out of the 22 prisons selected 12 as of $30^{\text {th }}$ June, 2010 were operating under capacity while 8 prisons located at the urban cities were congested operating almost twice their capacities example, Kaduna Borstal Training Institute with a capacity of 280 holds a population of 482 juveniles while Kauna Maximum, Kano, Goron, Dutsen, Gausau, Yelwa Yuri, Katsina, Funtua and Kafancha were apparently congested. These same prisons housed more ATPs than convicts' exception of Yelwa Yuri. Out of those not congested only Kano central has more ATPs, the rest have more convicted persons. While the sun total reveal there were more ATPs 696 against convicts with a population of 8,360 while the prison capacity in the overall was overcapacity with lock up of 2,855 above capacities of 6,494 .

Table (3) Capacity, Lockup, Number of Atps and Convicts in North Central Zone

\begin{tabular}{|c|c|c|c|c|}
\hline PRISON & Capacity & Luck up & Convict & Awaiting Trial \\
\hline \multicolumn{5}{|l|}{ Niger State } \\
\hline 1. Agaje & 60 & 3 & 12 & 1 \\
\hline 2. Bida & 200 & 69 & 49 & 20 \\
\hline 3. Kagara & 50 & 55 & 45 & 10 \\
\hline 4. Lapai & 63 & 64 & 63 & 1 \\
\hline 5. New Bussa & 288 & 68 & 42 & 26 \\
\hline \multicolumn{5}{|l|}{ Nasarawa State } \\
\hline 6. Keffi & 130 & 280 & 9 & 181 \\
\hline 7. Lafia & 300 & 316 & 63 & 251 \\
\hline 8. Nasarawa & 104 & 31 & 24 & 6 \\
\hline 9. Wamba & 68 & 47 & 40 & 7 \\
\hline \multicolumn{5}{|l|}{ Kwara } \\
\hline 10. Ilorin & 122 & 298 & 70 & 228 \\
\hline 11. Lafiagi Farm & 34 & 45 & 44 & 1 \\
\hline \multicolumn{5}{|l|}{ Kogi State } \\
\hline 12. Ankpa & 30 & 27 & 14 & 12 \\
\hline 13. Dekina & 34 & 23 & 16 & 18 \\
\hline 14. Idah & 102 & 23 & 17 & 6 \\
\hline 15. Kabba & 200 & 68 & 38 & 30 \\
\hline 16. Koton Karfe & 50 & 131 & 17 & 114 \\
\hline $\begin{array}{l}\text { 17. Medium Security } \\
\text { Okene }\end{array}$ & 114 & 102 & 48 & 54 \\
\hline 18. Lakushi Farm & 150 & 52 & 52 & - \\
\hline 19. Lantang & 150 & 34 & 24 & 10 \\
\hline 20. Jos & 1,150 & 771 & 216 & 555 \\
\hline 21. Shendam & 130 & 51 & 30 & 21 \\
\hline 22. Wase & 100 & 21 & 20 & 1 \\
\hline 23. Panshin & 162 & 55 & 22 & 32 \\
\hline \multicolumn{5}{|l|}{ Benue State } \\
\hline 24. Gboko & 810 & 220 & 118 & 102 \\
\hline 25. Makurdi & 280 & 481 & 96 & 385 \\
\hline 26. Otukpo & 118 & 85 & 28 & 57 \\
\hline \multicolumn{5}{|l|}{ FCT Abuja } \\
\hline 27. Kuje & 320 & 669 & 136 & 533 \\
\hline 28. Suleja & 250 & 358 & 187 & 171 \\
\hline Total & 5,569 & $\mathbf{4 , 4 5 7}$ & 1,591 & 2,817 \\
\hline
\end{tabular}

The table above shows that in this zone, only five prisons, Ilorin, Keffi, Makurdi, Kuje and Suleja were congested reflecting the trend of city prisons overcrowding while those in the suburbs are not. Kuje, Suleja, Jos. Ilorin, Okene, Katon, Karfe, Kabba and Jos have higher number of ATPS more than convicted prisons. The 
zone was generally operating below capacity; it has the capacity of 5,569 but housed 4,457 inmates. The number of ATPs as of $30^{\text {th }}$ June, 2010 was 1,591 far above the convicts of 281 .

Table (4) Capacity, Lockup, Number of Awaiting trials And Convicts South East Zone

\begin{tabular}{|l|l|l|l|l|}
\hline Prison & Capacity & Lock up & Convicts & Awaiting Trial \\
\hline Abia State & & & & \\
\hline 1. Aba & 500 & 483 & 114 & 369 \\
\hline 2. Umuahia & 400 & 980 & 46 & 734 \\
\hline Ebonyi State & & & & \\
\hline 3. Abakaliki & 388 & 938 & 92 & 846 \\
\hline 4. Afikpo & 200 & 104 & 23 & 81 \\
\hline Enugu State & & & & 1,045 \\
\hline 5. Enugu & 638 & 1,042 & 169 & 126 \\
\hline 6. Oji River & 320 & 146 & 20 & \\
\hline Imo State & & & & 1,433 \\
\hline 7. Owerri & 548 & 1,580 & 143 & 217 \\
\hline 8. Okigwe & 540 & 264 & 47 & \\
\hline Anambra State & & & & 855 \\
\hline 9. Onisha & 326 & 898 & 43 & 470 \\
\hline 10. Akwa & 238 & 497 & 27 & Nil \\
\hline 11. Orreh Farm & 100 & 48 & 48 & 28 \\
\hline 12. Arochukwu & 180 & 51 & 22 & Nil \\
\hline 13. Ibite-olo & 250 & 55 & 55 & $\mathbf{6 2 0}$ \\
\hline Total & $\mathbf{4 6 2 8}$ & $\mathbf{6 8 8 6}$ & $\mathbf{8 4 9}$ & \\
\hline
\end{tabular}

Overcrowding in this zone is seven out of 13 prisons all located in the cities such as Owerri, Umuhia, Enugu, Akwa, Onitsha, Abakiliki, and Aba prisons. In all these prisons, ATPs far outnumbered those convicted in nine prisons and housed inmates over capacity. The total sum shows that the zone has the capacity of 4628 but house 2886 above twice its capacity while at of $30^{\text {th }}$ June, 2010 the number of convicts was 849 above ATPs with a population of 620 inmates.

Table (5): Capacity, Lockup, Population of Atps and Convicts in South West Zone

\begin{tabular}{|c|c|c|c|c|}
\hline Prison & Capacity & Lock up & Convicts & Awaiting Trial \\
\hline \multicolumn{5}{|l|}{ Lagos State } \\
\hline 1. Kirikiri Female & 106 & 170 & 34 & 136 \\
\hline 2. kirikiri Medium & 704 & 1,680 & 172 & 1,508 \\
\hline 3. Kirikiri Maximum & 1056 & 880 & 255 & 625 \\
\hline 4. Badagry & 130 & 310 & 111 & 215 \\
\hline 5. Ikoyi & 800 & 1,745 & 111 & 1,634 \\
\hline \multicolumn{5}{|l|}{ Oyo State } \\
\hline 6. Agodi & 394 & 646 & 69 & 577 \\
\hline \multicolumn{5}{|l|}{ 7. Оуо } \\
\hline \multicolumn{5}{|l|}{ Ekiti State } \\
\hline 8. Ado Ekiti & 200 & 309 & 54 & 255 \\
\hline \multicolumn{5}{|l|}{ Ondo State } \\
\hline 9. Akure Medium & 320 & 541 & 49 & 492 \\
\hline 10. Owo & 180 & 80 & 43 & 37 \\
\hline 11. Okitipupa & 66 & 76 & 39 & 37 \\
\hline 12. Ondo & 80 & 72 & 22 & 50 \\
\hline \multicolumn{5}{|l|}{ Osun State } \\
\hline 13. Ilesha & 586 & 381 & 77 & 304 \\
\hline 14. Ile-Ife & 320 & 147 & 26 & 121 \\
\hline \multicolumn{5}{|l|}{ Ogun State } \\
\hline 15. Abeokuta & 502 & 830 & 249 & 578 \\
\hline 16. Ijebu-ode & 49 & 298 & 28 & 270 \\
\hline 17. Shagamu & 48 & 174 & 7 & 167 \\
\hline 18. Ilaro & 126 & 222 & 27 & 195 \\
\hline Total & 5670 & 8831 & 1372 & 7201 \\
\hline
\end{tabular}

Out of the 19 prisons in the zone, 8 prisons in the suburb are operating under capacity while 11 prisons in the major towns Akure medium, Ikoyi, Agodi, kirikiri female, Badagary, Ado Ekiti, Shagamu, Ejebu-Ode and Abeokuta were congested with higher ATPS and five other prisons not overcrowded holds more awaiting trial persons than convicted persons. On a general summation, the zone with a capacity of 5670 was housing 8831 inmates well over its capacity. On $30^{\text {th }}$ of June, 2010, the number of convict was 1372 which was below the number of ATPs with a population of 7201 . 
Table (6): Capacity, Lockup, Awaiting trials and Convicts in South-South Zone

\begin{tabular}{|c|c|c|c|c|}
\hline Prison & Capacity & Lock up & Convicts & Awaiting Trial \\
\hline \multicolumn{5}{|l|}{ Akwa Ibom State } \\
\hline 1. Abak & 200 & 134 & 30 & 104 \\
\hline 2. Eket & 124 & 173 & 40 & 133 \\
\hline 3. Ikot Abasi & 400 & 132 & 43 & 89 \\
\hline 4. Ikot Ekpene & 614 & 466 & 137 & 333 \\
\hline \multicolumn{5}{|l|}{ Cross River } \\
\hline 5. Obudu & 50 & 24 & 13 & 11 \\
\hline 6. Ogoja & 400 & 42 & 14 & 38 \\
\hline 7. Ikom & 200 & 57 & 15 & 57 \\
\hline 8. Obubra & 128 & 79 & 29 & 50 \\
\hline 9. Calabar & 250 & 611 & 86 & 525 \\
\hline \multicolumn{5}{|l|}{ Delta State } \\
\hline 10. Agbor & 179 & 185 & 12 & 173 \\
\hline 11. Kwale & 262 & 184 & 33 & 141 \\
\hline 12. Ogwashi-Uke & 64 & 319 & 46 & 273 \\
\hline 13. Sapele & 294 & 263 & 27 & 263 \\
\hline 14. Warri & 307 & 556 & 156 & 400 \\
\hline \multicolumn{5}{|l|}{ Edo State } \\
\hline 15. Auchi & 200 & 185 & 36 & 148 \\
\hline 16. Benin city & 1,216 & 879 & 83 & 796 \\
\hline 17. Oko & 307 & 523 & 122 & 401 \\
\hline 18. Ogba Prison farm & 106 & 53 & 53 & Nil \\
\hline 19. Ozalla farm & 200 & 150 & 50 & Nil \\
\hline 20. Ubiaja & 240 & 141 & 31 & 110 \\
\hline \multicolumn{5}{|l|}{ River State } \\
\hline 21. Ahoada & 150 & 347 & 74 & 273 \\
\hline 22. Elele farm & 200 & 70 & 70 & Nil \\
\hline 23. Port Harcourt & 804 & 2,927 & 284 & 2,636 \\
\hline Total & 6645 & 7941 & 6897 & 6897 \\
\hline Ground total & 33122 & 41603 & 15874 & 25547 \\
\hline
\end{tabular}

Source: Department of Planning and Statistics, Prison headquarter, Abuja \& Ayade 2010

The same trend of congestion in prisons at urban centres is evinced in South, South zone eight prisons: Calabar, Oko, Warri, Ikot-Abasi, Kwashi-Uke, Agbor, Port-Harcourt and Ahoada out of twenty four are overcrowded with more ATPs. Benin and Sapele Presents rare case scenario where there was no congestion in prison in the urban centres. As of $30^{\text {th }}$ June, 2010 the number of inmate houses in the zone was above capacity which is 5357 while the lockup was 8443 . It also showed that the ATPs was equal the number of convicts.

\section{Implications for reformation, rehabilitation and reintegration}

Reformation: This is the process of making the inmate better by trying to change his delinquent behaviours. It means infusing in him the will to refrain from criminal behaviour. Article 59 of the United Nations on minimum standard rules for the treatment of offenders' states: To this end (Reformation) the institution should seek to utilize all the remedial, educational, moral, spiritual, and other forces and forms of assistance, which are appropriate and available and should seek to apply them according to the individual treatment needs of the prisoner.

Rehabilitation: Prison rehabilitation means bringing the offender to normal life. According to Omoni \&Ijeh (2009), rehabilitation is a transitional or after-care service rendered to inmates to avoid revolving-door rearrests. To rehabilitate an inmate, he/she must be "straightened out" deep within his/her own personality. He/she maintains that the rehabilitative activities of the modern prison which generally have been of two kinds: Psychological or psychiatric treatment and Educational or vocational programmes.

Reintegration: This is the process of preparing inmate in a reformed and rehabilitated manner back to the society. This is achieved by engaging inmates in a useful programmes like: educational programme that would enable inmates leave the prison with more skills and be in a position to find meaningful and long- term employment (Rhode, 2004). Also, vocational programme that will provide job training that prepares inmates with the know-how and training for today's workplace. Inmates can be trained in carpentry, construction trades, computer programs and repair, horticulture, painting, plumbing and much more.

\section{Conclusion and Recommendations}

This assessment does appear to have implications both for prison authorities and Prison Inmates as well. For the Nigeria Prison Authorities, the International Standards states that each prisoner must have enough space, although definitions of adequacy vary from country to country and depend among other factors on how 
much tire prisoner spend in their cells. It is one thing to sleep in a confided space another to spend 23 hours a day there. The UN Standard Minimum Rules do say that all cells and perimeter walls and dormitories must have adequate heating, lighting and ventilation and that every detainee or inmate should have his/her own bed or mattress with clean bedding to enhance the psychological wellbeing of the inmate. But this study discovered that many of these inmates fall short of these basic needs.

Moreover, the prisons of study for this research work hold more prisoners than the official capacity. By implication, the minimum required standard in respect of dimensions eg. Minimum space per prisoner of not less than $3.4 \mathrm{sq}^{\mathrm{m} 1}$ and area within the security perimeter of $20-30$ sqm person was not observed. This clustering and crowding of prisoners together in a choky cell that in originally may be meant for five inmates and housing 20 - 30 inmates may arouse violent and aggressiveness among the inmates. In most prisons, there tends to be more overcrowding among the awaiting trial male (ATM) then the convicted as revealed from the study. As a result, there is a need to keep the awaiting trials apart completely from the convicted prisoners because this may lead to gross violence of prison unrest since most often both the awaiting trials and convicted do have some things in common.

As for the prison inmates, the circumstances may differ for non-violent inmates in a crowded environment. For such individual inmates, any violent behaviour manifested may, in fact, be in response to their environment. Yet, it is not the restrictiveness, but the dangerousness of the environment that compels nonviolent inmate to engage in aggressive acts. In order to improve inmate conditions in overcrowded prisons, having identified that prison overcrowding contributed to the following problems: reduced staff morale, security and control difficulties, staff and inmate health and wellbeing problems, increased levels of conflicts and violence; and failure of rehabilitation resulting in increased re-offending it is recommended that:

Clinical Psychologists have significant role to play in the areas observing the personality, victim empathy and remorse; language and body movements of the inmate and gives psychological interpretations to them. The Clinical psychologist would help to identify the personality type (A or B), noting that Type A are achievers and risk takers and Type $\mathrm{B}$ are hedonists. The implications of this are that trying to achieve by all means or taking too much risk (as in Type A) could lead to crime. Equally, wanting to live life to the fullest without stress or hard work (as in Type B) could as well lead to crime. It as a result of psychological assessment that would also help to cognitively interpret the offender-e.g. the kind of schemas the offender holds (does he/she glamorised violent culture, etc). Is the offender remorseful, or does he/she thinks that he/she is a victim of State crime). This could help to interpret his/her risk level (low, medium, high) to the prison population; and the community and society to which he would return.

\section{References}

[1] Aduba , J. N (2005). Overcrowding in Nigeria Prisons: a Critical Appraisal. Retrieved from; http://dspace.unijos.edu.ng/bitstream/10485/186/1/21\%2OVERCROWDING.pdf.on 10/01/2012

[2] Ayade, E. A. (2010). Problems of Prisons Overcrowding in Nigeria: Some lessons from South Africa and America. LLM, Human Rights, Unpublished Thesis, Central European University, Legal Studies Department, Budapest, Hungary.

[3] Cox, V., Paulus, P., \& McCain, G. (2004). Prison Crowding Research: The Relevance of Prison Housing Standards and a General Approach Regarding Crowding Phenomena. American Psychologist, 39, 1148-1160.

[4] Crystal, A. B. (2004). Overcrowding and Violence in federal correctional institution: An Empirical Analysis. Ph.D. Thesis, Drexel University.

[5] Johnson, J.C. (2001). A Psychological perspective on the new design concepts for William Head Institution (British Columbia). Forum on Corrections Research, 3, 14-21.

[6] Omoni, G. E \& Ijeh, S. U. (2009). Qualitative education for prisoners: A panacea to effective rehabilitation and integration into the society. Edo Journal of Counselling. Vol 2, no 1, pp 28-37

[7] Rhode, L. (2004). What is wrong with prison? Heart and Minds Network, Inc. www.employeradvisorsnetwork.com/documents $/ 21^{\text {st }}$ centuryfirm.pde 